\title{
Physical Work Environment Effect on Employee Productivity of Textile Industry
}

\author{
Masharyono, Sumiyati, Toyib \\ Universitas Pendidikan Indonesia \\ Setiabudhi No. 229 Bandung \\ masharyono@upi.edu
}

\begin{abstract}
The problem of the background for this study is the problem of employee productivity is still a major problem in a variety of industries and companies, in which the quality of human input is an important factor in increasing productivity to economic growth and development. The purpose of this study to determine the influence of the physical work environment on employee productivity. Design / methodology / approach in this study conducted at intervals of less than one year, then the design study is a cross-sectional method. This study used a descriptive approach and verification with explanatory survey method. A total of 145 respondents were selected as the sample using probabiliti sampling. Research questionnaire used as a research instrument to collect data from respondents, as well as the data analysis technique used is a simple linear regression. The findings explain that the physical work environment influence on employee productivity.
\end{abstract}

Keywords- Physical Work Environment, Employee Productivity

\section{INTRODUCTION}

The employee's productivity is still a major problem in a variety of industries and companies, in which the quality of human input is an important factor in increasing productivity to economic growth and development. The low productivity of labor take place on sharing industry, including the textile industry. Though the textile industry and textile products (TPT) offers an important opportunity for a country to start the industrialization of its economy. Efforts in increasing the productivity of the textile industry is an important indicator of the economy and the market value of the company. This is because the textile industry can absorb labor in large scale and indirectly impact on improving the economy of a country [1] [2].

Productivity is widely regarded as key success factors of the organization and is generally defined as a measure of the amount of output produced per unit of input. So that one measure of the success of the performance of individuals, teams or organizations located in productivity. When productivity is high or increasing then declared successful, then if lower than the standard or declining, say no or less successful [3] [4].

Effect of employee productivity associated with various factors, especially physical work environment that directly relate to the operations of the company. Physical work environment has an effect on the productivity of employees. Conditions of the physical work environment affects the functions of the employees and will determine the well-being of the organization. So that the physical work environment can design improved productivity and impact on profit for the company [5] [6].

Based on the explanation above, it can be said that the causes of low productivity of employees related to the physical work environment around the workplace. Thus the problem of employee productivity need to be addressed, so as not to hamper the operations of the company in achieving its intended purpose. As this study aims to gain (1) description of the physical work environment, (2) description of the employee's productivity, and (3) influence of the physical work environment on employee productivity.

\section{LITERATURE REVIEW}

Humans are the driving factor productivity which is owned by a company. Effectiveness and efficiency will not mean the achievement of corporate goals without the support of qualified human resources [7]. Productivity is the ratio between the output (output) is achieved with the input (input) required to produce output, especially in terms of quantity. Therefore, the productivity level of each employee can be different, it could be too high or low, depending on the degree of persistence in performing tasks. Labor productivity is basically made up of two types of behaviors simultaneously, namely the behavior of effective and efficient in implementing the work according to a set plan [8] [9] [10].

Dimensions to measure labor productivity in this study refers to the theory advanced by Sutrisno Edy, (2010:211-212), such as: ability, improve the results achieved, morale, selfdevelopment, quality and efficiency. Each company is always desirous that manpower that owned able to increase productivity high. The employee's productivity is affected by several factors, both related to labor itself as well as other factors, such as level of education, skills, discipline, attitude and work ethic, motivation, nutrition and health, level of income, social security, work environment, work climate, technology, production facilities, management and achievement [11]. Physical work environment are all circumstances the physical form contained around the workplace that may affect the employees, either directly or indirectly components associated with the ability of carrying 
out the work is physically connected to the work environment that affect employees in carrying out their duties burden [12] [5] [13]. Dimensional physical work environment by [12], including: work equipment, working facilities, lighting or light, temperature or the air temperature, humidity, air circulation, noise, mechanical vibration, and job security.

\section{RESEARCH METHODS}

This study was conducted to determine the effect of the physical work environment on employee productivity. As for the independent variable in this study is the physical work environment, as well as the dependent variable is the employees' work productivity. The population in this study were 397 respondents, while the formula used to measure samples in this study used a formula of [14], so that the minimum sample size in this study was determined by $k=0.05$ then obtained a sample size (n) minimum of 145 samples of the production employees PT. Garuda Mas Semesta (Gamatex) Cimahi. Data collected by spreading questionnaire.

This research was conducted at the timeframe of less than one year, the research method used is cross sectional method. The type of research that is used is a verification study. The nature of verification basically wanted to test the truth of a hypothesis which is implemented through field data collection [15] then in this study will be tested on how much influence the physical work environment on employee productivity. Based on the type of the study, the method used in this research is explanatory survey aimed to test the hypothesis of one variable with another variable.

\section{RESULTS}

Tests in this study using the Test $\mathrm{F}$ with the aim to determine the effect that the simultaneous physical work environment to variable productivity of employees using regression significance test. The test results using test Ftest available Fhitung amounting to 11827 for the physical work environment with a level of significance $0.000 \leq 0.05$ means the physical work environment overall regression model can be used to predict the productivity of employees linear patterned. Testing the influence of independent variables on the dependent variable by using test $F$ that is Fhitung $>$ Ftabel. Then F table with 145 respondents are in $=0.05$ amounted 3.09. Thus obtained Fhitung $>$ Ftabel or $11.827>3.09$, then Ho rejected. So it can be said that the physical work environment influence on employee productivity.

The regression model used in this study is a simple linear regression that aims to predict the rise and fall of the dependent variable, and independent variables as predictor's factors that manipulated. Simple linear regression equation between physical work environments on employee productivity, as follows:

Employee Productivity $=38.464+0.236$ (Physical Work Environment)

Based on simple linear regression equation above, the constant of 38 464, stating that if the physical working environment is not repaired or upgraded (physical work environment $=0$ ) the productivity of employees 38464 worth of the unit value. The regression coefficient of the unit value of 0.236 means that any increase in physical work environment will increase the productivity of employees by 0236 the unit value and vice versa if the decline in the productivity of employees, physical working environment will reduce the productivity of employees by 0236 the unit value.

To determine whether the physical work environment variable partial or no real effect on the dependent variable. Here below are the results of hypothesis testing using $t$ test $(t-$ Test). Ttest magnitude can be known through the t-test of 3,017 to physical work environment, while the amount ttabel=1.984, because the value thitung $>$ ttabel so: physical work environment $=3.017>1.984$ it can be concluded Ho rejected and $\mathrm{Ha}$ be accepted. The t-test results can be concluded that the hypothesis in this study is Ho refused and Ha is received, so that: there are significant physical work environment on the productivity of the production employees PT. Garuda Mas Semesta (Gamatex) Cimahi.

Based on the results of empirical research that the employee's productivity is affected by the physical work environment. The problem is employee productivity in the workplace, where the working environment is conducive to stimulate the creativity of workers. Improved working environment and poor working conditions contributed to the low productivity of employees [16]. Workplace environment plays an important role for employees, current employees may have a large number of alternative work, and then the environment in the workplace is an important factor for receiving and keeping a job. Environmental quality in the workplace can determine the level of employee motivation, the next performance and productivity. therefore contributes to the error rate, degree of innovation and collaboration with other employees, absenteeism and decreased morale [17]. This is according to research conducted by [5], states that there are linkages and the influence of the physical work environment on employee productivity. The working environment consists of components associated with the ability to carry out the work is physically connected to the office environment [5]. So that the physical working environment is everything that is around employees work affecting employees in carrying out their duties burden [13]. Other than that, [18], stated that the physical environment affects their welfare and directly affects the performance and productivity. In the workplace, it is often assumed that employees are more satisfied with the physical environment are more likely to produce better work. Temperature, air quality, lighting and noise conditions at work affects concentration at work and productivity.

Overall based on empirical research results in the form of the influence of the physical work environment and work discipline on employee productivity, that partially or simultaneously the employee's productivity is affected by the physical working environment around the workplace.

\section{CONCLUSIONS AND SUGGESTIONS}

Based on the description of theory and research has been done using descriptive analysis and verification as well as simple linear regression between the physical work environment on employee productivity part of production PT. 
Garuda Mas Semesta (Gamatex) Cimahi, it can be deduced that the physical working environment that are in good enough category and productivity of work at the high category. T test results showed that the physical work environment affects productivity of employees, where the increase in the physical working environment will affect the increased employee productivity. This study is expected to serve as information and incentive to conduct further research on the effect of physical work environment on employee productivity.

\section{REFERENCES}

[1] Iwan Hermawan. Analisis Dampak Kebijakan Makro terhadap Perkembangan Industri Tekstil Indonesia. 2011. 373-408.

[2] Shaikh, S. R., \& Dulange, S. R. A. Study of Factors Affecting Productivity of Power Loom Industries2(12),. 2013. 3174-3180.

[3] Nasiripour, A., M, A. K., \& Izadi, A. Effect of Different HRM Policies on Potential of employee Productivity, 1(6). 2012. 45-54.

[4] Wibowo. Manajemen Kinerja. Jakarta: PT. Rajagrafindo Persada. 2012.

[5] Ismail, J. The Influence of physical workplace environment on the productivity of civil servants: The case of the Ministry of Youth and Sports , 5(1), 2010. 71-78.

[6] Paul Roelofsen. The Impact of Office Environments on Employee Performance: The Design of the Workplace As a Strategy for Productivity Enhancement. 2000. http://doi.org/10.1108/14725960310807944

[7] Syamsul Hadi Senen. Pengaruh Motivasi Kerja dan Kemampuan Kerja Karyawan terhadap Produktivitas Kerja Karyawan pada PT. Safilindo Permata. Strategic, 7(September). 2008. 1-15.
[8] Tjutju Yuniarsih, S. Manajemen Sumber Daya Manusia. Bandung. Alfabeta. 2009.

[9] Sutrisno, E. Budaya Organisasi. Jakarta: Kencana Pernada Media Group. 2010.

[10] Ridwan Purnama. Pengaruh Motivasi Kerja Terhadap Produktivitas Kerja Karyawan Pada Bagian Produksi CV . Epsilon Bandung. Strategic. 2008. 7, 58-72.

[11] Sutrisno, E. Manajemen Sumber Daya Manusia. Jakarta: Kencana Pernada Media Group. 2011.

[12] Sedarmayanti. Sumber Daya Manusia dan Produktivitas Kerja. Bandung: CV. Mandar Maju. 2009.

[13] Hendri, E. Pengaruh Lingkungan Kerja Fisik dan Non Fisik Terhadap Kepuasan Kerja Karyawan pada PT. Asuransi Wahana tata Cabang Palembang. 2012. 1-16.

[14] Harun Al Rasyid. Teknik Penarikan Sampel dan Penyusunan Skala. Bandung: Universitas Padjajaran. 1994.

[15] Wibowo, L. A. Pengaruh Kinerja Kualitas Pelayanan Melalui Seven Romancing Moments Terhadap Pembelian Ulang Pada Restoran Hoka Hoka Bento Cabang Setiabudi Bandung. Strategic. 2009. 8, 1-11.

[16] Taiwo, A. S. The influence of work environment on workers productivity: A case of selected oil and gas industry in, 4(March), 2009. 299-307.

[17] Demet Leblebici. Impact of Workplace Quality on Employee's Productivity: Case Study Of a Bank in Turkey. 2012. 1, 38-49.

[18] N. Kamarulzaman, A. A. Saleh, S. Z. Hashim, H. Hashim, A. A. A.-G. An Overview of the Influence of Physical Office Environments Towards Employee Procedia Engineering An Overview of the Influence of Physical Office Environments towards Employees, 2011. http://doi.org/10.1016/j.proeng.2011.11.164 